\title{
ODNOS GLAZBENIH PREFERENCIJA SREDNJOŠKOLACA, GLAZBENOG OBRAZOVANJA I SOCIODEMOGRAFSKIH VARIJABLI
}

\section{Tihana Škojo}

\author{
Akademija za umjetnost i kulturu u Osijeku, \\ Sveučilište Josipa Jurja Strossmayera u Osijeku, \\ Hrvatska, tihana.skojo@uaos.hr
}

Primljeno: 23. 6. 2019.

\begin{abstract}
Brojni čimbenici koji utječu na oblikovanje glazbenih preferencija srednjoškolaca upućuju na zahtjevnu ulogu glazbenih pedagoga. Njihov je zadatak da kompetentnim i kreativnim glazbenim poučavanjem navedu učenike da s emocionalno konotacijskog pristupa započnu primjenjivati sintaktičku strategiju slušanja, s razvijenim analitičkim muzikološkim procesima, te postupno razviju glazbeni ukus s kvalitetnim estetskim sustavom vrijednosti. Istražujući odnos sociodemografskih varijabli i glazbenih preferencija učenika prvih i četvrtih razreda gimnazije $i$ strukovne srednje škole potvrđene su razlike u poznavanju $i$ preferencijama utvrđenih glazbenih stilova s obzirom na spol, vrstu škole, dob i školski uspjeh. Kroz dobivene rezultate istraživanja aktualizirana je potreba za uvrštavanjem glazbene poduke u strukovnim školama, obrazovnim institucijama u kojima takvi sadržaji nisu zastupljeni, ali i potreba za programskim proširenjima kako bi mladi u svojoj formativnoj fazi uz izgradnju pozitivnog odnosa prema umjetničkoj glazbi razvijali i otvorenost te toleranciju prema različitim kulturama i supkulturnim fenomenima.
\end{abstract}

Ključne riječi: glazbene preferencije adolescenata, glazbena poduka, umjetnička glazba, popularna glazba, glazbe svijeta

\section{Uvod}

Glazba je oduvijek imala značajan utjecaj u osobnim i društvenim životima mladih. Njezin utjecaj možemo promatrati kroz aspekt 
zadovoljavanja brojnih čovjekovih potreba, u funkcionalnom smislu. Shvaćanje glazbe kao sredstva kojim se utjecalo na afektivna stanja te koristilo u odgojne svrhe i utjecalo na društvo (Breitenfeld i Majsec Vrbanić, 2011) datira još iz davnina, posebice iz doba stare Kine i antičke Grčke. Funkcionalno utemeljena uloga glazbe i slušanje glazbe, kao najčešća glazbena aktivnost, poprimala je značajke sukladne kontekstu u kojemu se slušanje odvijalo. Ovisno radi li se o glazbi kao sastavnome dijelu zabave, pozadinskom ugođaju svakodnevnih životnih rituala, elementu kojim se iskazuju stavovi i opredjeljenja ili o umjetničkom doživljaju, u svakom od ovih konteksta slušanje rezultira kratkoročnim procjenama sviđanja, odnosno glazbenim preferencijama. Glazbene su preferencije individualne prirode i ovise o brojnim čimbenicima (Rentfrow i Gosling, 2003). Ovise o osobinama slušatelja, emocionalnom stanju slušatelja (Larson, 1995), afektivnom iskustvu slušatelja, društvenom utjecaju (Sagalnik, Dodds i Watts 2006), kulturološkom identitetu slušatelja (Frith, 1996) te u konačnici o glazbenom odgojnoobrazovnom stupnju slušatelja.

Okolina i vršnjaci te masovni mediji svakako su najznačajniji čimbenici koji utječu na usmjeravanje glazbenih preferencija mladih. Mladi odabiru glazbu s ciljem ostvarivanja povezanosti sa skupinom vršnjaka (Baptiste i Augustin, 2009) i ostvarivanja personalnih i interpersonalnih ciljeva (Lull, 1985). Stoga su glazbene preferencije u adolescentskoj populaciji najčešće usmjerene prema oblikovanju društvenog identiteta (Getz, Marks i Roj, prema North, Hargreaves i O'Neill, 2000) i bitan su čimbenik u poistovjećivanju mladih s brojnim socijalnim elementima društvene skupine. Mediji, posebice suvremena sredstva za produkciju i reprodukciju zvuka, omogućili su masovno širenje glazbe i postavili glazbu niske kvalitete u središte životnih navika mladih. Glazba je postala sveprisutna i dostupna svima, a time je utjecaj masovnih medija na glazbene preferencije postao dominantan i vodeći po utjecajnosti (Škojo, Radočaj-Jerković i Milinović, 2006). Glazbene su se preferencije, pod utjecajem masovnih medija, usmjerile prema glazbi koja je plasirana po tržišnim pravilima i ciljevima, ne obazirući se na kulturno uzvišenije ciljeve (Šuran, 2013). Poznato je da najveći dio emitirane glazbe putem masovnih medija pripada žanru popularne, zabavne glazbe, za koju nije potrebno uložiti mentalni angažman kako bi zadovoljila potrebe pasivnog slušanja (Gaggiolo, 2003; Lamont et al., 2003) kakvo najčešće zadovoljava potrebe današnje mladeži. Za razliku od pasivnog 
konzumiranja glazbe, intencijsko slušanje glazbe u kojemu je prezentirana glazba, njezina estetska vrijednost i umjetnički doživljaj kao konačni cilj spoznajnog procesa, čini osnovu glazbeno-obrazovne intervencije sa svrhom usmjeravanja preferencija mladih prema glazbeno vrijednim djelima. S estetske strane glazbena intervencija, koja se događa prvenstveno na nastavi ali i na brojnim izvannastavnim aktivnostima u okviru projektnih aktivnosti i radionica, čini značajan utjecaj na glazbene preferencije mladih s namjerom da mladi s emocionalno referencijalnog pristupa prema glazbi počnu primjenjivati sintaktičku strategiju slušanja s razvijenim analitičkim muzikološkim procesima (Smith, 1987) i postupno razviju kvalitetan sustav vrijednosti i glazbeni ukus.

\section{Emocionalni aspekt glazbenih preferencija mladih}

Suvremena je znanost temeljem brojnih istraživanja utvrdila utjecaje glazbe na emocionalna stanja adolescenata. Istraživanja emocionalnih procesa pod utjecajem glazbe ukazuju na mogućnost reguliranja emocija te uloge glazbe kao stabilizatora raspoloženja (Saarikallio, 2008). Razni emocionalni čimbenici, koji se odnose na pozitivne i negativne, sedativne ili pobuđujuće osjećajne podražaje predstavljaju temelj za usmjeravanje glazbenih preferencija mladih (Larson, 1995). Kuntsche, Le Mevel i Berson (2016) utvrđuju motive za slušanje glazbe i ukazuju na poveznicu s agresivnim i depresivnim raspoloženjem. Eysenck (1990) naglašava kako se prilikom odabira glazbe odlučujemo upravo za onu vrstu glazbe koja će voditi optimalnoj razini uzbuđenja. Lippman i Greenwood (2012) ukazuju na poveznicu između glazbenih preferencija mladih i vlastitih emotivnih iskustava te naglašavaju kako su emocionalni čimbenici i osjećajni podražaji često potaknuti evociranjem pozitivnih ili negativnih uspomena. Brojni autori u svojim radovima naglašavaju povezanost glazbenih preferencija mladih s osobinama ličnosti (Arnett, 1995; Gantz et al., 1978) i utvrđuju kako je prilikom donošenja obuhvatnijih zaključaka potrebno pozornost usmjeriti i na ovaj utjecaj. Schäfer, Smukalla i Oelker (2014) istražuju jačinu preferencija za određenu vrstu glazbe i predlažu teorijski model razvoja glazbenih preferencija koji je usmjeren prema motivima za slušanje glazbe.

Kod istraživanja povezanosti emocionalnih stanja i preferencije adolescenata, autori svoju pozornost usmjeravaju prema utjecaju poje- 
dinih vrsta glazbe i glazbenih osobina te glazbenih izražajnih elemenata. Thompson et al. (2001) dolaze do zaključka kako Mozartova glazba uspješnije otklanja napetost i pospješuje bolje raspoloženje nego glazba baroknog skladatelja Tomasa Albinonija. Uhlig, Jensen i Scherder (2015) utvrdili su utjecaj rap glazbe i uporabe tog glazbenog žanra kao učinkovitog samoregulacijskog alata za kontrolu emocija u školama u svrhu prevencije nasilnog ponašanja. Scheel i Westefeld (1999) utvrdili su kako heavy metal glazba značajno utječe na poticanje negativnog raspoloženja adolescenata, dok Cripe (1986) utvrđuje pozitivan utjecaj rock glazbe na raspoloženje ispitanika, ali i na poremećaj pozornosti kod učenika. Van der Zwaag et al. (2011) su temeljem glazbenih sastavnica, tonaliteta, tempa i dinamike na primjerima pop i rock pjesama istraživali utjecaj na fiziološke funkcije i povezanost s emocionalnim stanjem slušatelja. Navode kako mladi iskazuju preferencije prema glazbi koja ih vodi prema poželjnom emotivnom stanju. S aspekta glazbeno izražajnih sastavnica, istraživači zaključuju kako je tonalitet povezan s glazbenim preferencijama. Crowder (1984) zaključuje kako postoji opravdana povezanost durskog tonaliteta s emocijom sreće i molskog tonaliteta s tužnim emocijama. Burnsed (2001) utvrđuje kako mladi preferiraju djela u kojima je prisutna ekspresivna dinamika te navodi razvojnu tendenciju preferencija koje impliciraju na povezanost s glazbenom podukom. LeBlanc i Cote (1983) ukazuju na preferenciju mladih prema glazbi bržeg tempa. Isti autori, istražujući utjecaj izvođačkog medija na glazbene preferencije, utvrđuju kako mladi preferiraju instrumentalne ulomke u odnosu na vokalne. Također, autori navode preferenciju ženskih ispitanika prema ženskim glasovima, a muških ispitanika prema muškim vokalima. LeBlanc i Sherrill (1986) ukazuju na preferenciju mladih prema glazbi niske razine vibrata, a LeBlanc et al. (1992) istraživanjem ukazuju na preferencije prema glazbi s visokom razinom humora.

Sva su ova saznanja glazbeno-psiholoških istraživanja vrijedan doprinos glazbenim pedagozima prilikom određivanja slušnog repertoara u najosjetljivijoj formativnoj fazi za razvoj glazbenih preferencija.

\section{Uloga glazbene poduke u razvoju glazbenih preferencija}

Slušanje, u kojemu se glazba tretira kao cilj, u intencijske svrhe, predstavlja mentalno aktivno i analitičko pristupanje slušatelja glaz- 
benom djelu. Za razliku od pasivnog slušanja, u kojemu se slušatelj prepušta glazbi i fiziološki prima zvukovne podražaje pri tome ne usmjeravajući pozornost na detalje djela ili djelo u cijelosti, aktivno slušanje zahtjeva da slušatelj postane skladateljev suradnik (Andreis, 1967, 288). Hargreaves i Colman $(1981,16)$ aktivno slušanje nazivaju objektivno-analitičkim slušanjem i razlikuju ga od afektivnog slušanja u kojemu je dominantan jednostavan emocionalni stav slušatelja prema djelu.

Slušanje u glazbenoj poduci, kao objektivno-analitičko slušanje, primarno je zasnovano na analizi i zapažanju izražajnih elemenata (melodije, harmonije, boje, dinamike, ritma, tempa, glazbene forme i oblika). Richter na sličan način utvrđuje aktivan oblik slušne aktivnosti te ukazuje na razlike između slušanja koncentriranog na detalje, slušanja koncentriranog na cjelinu, slušanja kao spoznaje i slušanja u svrhu razumijevanje nekog problema (Richter, 1978, prema Rojko, 1996, 141).

Aktivno slušanje predstavlja najzahtjevniji oblik slušanja koje obuhvaća hijerarhijski stupnjevane kognitivne i psihomotoričke razine ciljeva. Oni se kreću od razumijevanja odslušanog, primjene upoznatog slušnog sadržaja, analize i sinteze različitih glazbenih pojavnosti, izražajnih sredstava glazbe i glazbenih sastavnica, principa organizacije djela, glazbenih oblika i vrsta, opusa najznačajnijih skladatelja, skladbi klasične, tradicijske i popularne glazbe. Tek razvijenom sposobnošću aktivnog, analitičkog slušanja, slušatelj u potpunosti upoznaje glazbu i gradi glazbena znanja, a kao posljedicu stjecanja znanja on izgrađuje osobna gledišta (Rojko, 2007, 73). Prožimanjem psihomotoričkog i kognitivnog područja slušatelj postupno izoštrava slušno iskustvo te razvija i proširuje interes za slušanje vrijedne glazbe. Tek nakon proširenih glazbenih preferencija prema kvalitetnoj, umjetnički vrijednoj glazbi, on će razviti i intrinzičnu motivaciju koja će rezultirati sudjelovanjem u glazbenom životu društvene sredine, kao aktivni sudionik u različitim orkestrima i zborovima ili kao slušatelj i posjetitelj glazbenih događanja. S vremenom slušatelj s ovakvim poželjnim afektivnim osobinama dolazi do najvišeg cilja: razvijanja glazbenog ukusa (Škojo, 2016).

Sa sadržajne strane, od osobite je važnosti da se slušanje realizira na glazbeno-estetski najvrjednijim djelima. Aktivnim slušanjem najznačajnijih djela svjetske i nacionalne literature, tradicijske glazbe kao i glazbe svijeta slušateljeve se glazbene preferencije usmjeravaju prema estetski vrijednim glazbenim ostvarenjima različitih glazbenih 
vrsta i žanrova. Gregory (1994) naglašava direktnu vezu između glazbene poduke i prijemčivosti učenika prema glazbi različitih vrsta i stilova. Upravo je glazbeno odgojno-obrazovna intervencija, usmjerena prema formiranju glazbenog ukusa i pozitivnog odnosa prema umjetničkoj glazbi, od najvećeg značaja u adolescentnoj dobi slušatelja, jer su glazbene preferencije najviše sklone promjenama tijekom razdoblja mladenaštva. Glazbena poduka rezultirat ce razvijenijim preferencijama prema umjetnički složenijoj i vrjednijoj glazbi (Moore i Johnson, 2001). Uslijed razvijenijih glazbenih sposobnosti ${ }^{1}$ mladi će imati razvijeniji kritički mehanizam vrednovanja složenije i estetski vrjednije glazbe (Le Blanc,1982).

Njirić $(1974,9)$ utvrđuje kako se konačan sud o djelu donosi tek nakon nekoliko uzastopnih slušanja istog djela, a samo se čestim slušanjem stječe slušalačka praksa i razvija interes za ovu umjetničku granu. Rojko $(2005,10)$ zaključuje kako se rijetke umjetnički vrijedne skladbe primaju nakon prvog slušanja te iz toga proizlazi kako je za upoznavanje i otkrivanje prave vrijednosti skladbe u svakoj obrazovnoj intervenciji neophodno glazbeno djelo slušati više puta. Temeljem utvrđenih metodičkih saznanja brojni autori usmjeravaju svoju pozornost na ispitivanje formiranja glazbenih preferencija i višekratnog slušanja. Shehan (1981) navodi kako ponovljeno slušanje djela i poznatost glazbe rezultira povećanim glazbenim preferencijama. Gilliland i Moore ukazuju na značaj glazbene intervencije na umjetnički složenijim djelima i navode kako se s višekratnim ponavljanjem pojačavaju glazbene preferencije prema djelima klasične glazbe, dok s brojem ponavljanja opada preferencija prema zabavnoj glazbi (Gilliland i Moore, 1927, prema Rojko, 1996, 145).

»Ponovljenim slušanjem anticipiraju se prethodno upoznata mjesta poput gradijenta cilja u labirintu, što proširuje gradijent zadovoljstva unatrag. Postizanjem vrhunca, nastupa opuštanje i zadovoljstvo opada.« (Mull, prema Farnsworth, 1969, 130)

Krugman je istraživanjem potvrdio istu hipotezu utvrdivši da popularna glazba brže doseže maksimum sviđanja nego klasična glazba što uzrokuje znatno raniju pojavu zasićenosti (Krugman, 1943). Downey i Knapp utvrdili su da ugoda pri ponavljanju raste kod suptilnijih skladbi

${ }^{1}$ Pojam 'glazbena sposobnost' sagledavamo u najširem obliku, kao središnju točku između glazbene podobnosti (potencijala) i postignuća (učinka) (Farnsworth, 1969, prema Mirković Radoš, 1996). 
i skladbi veće estetičke vrijednosti (Downey i Knapp, 1927, prema Rojko, 1996, 146). Potvrdu o značaju glazbene odgojno-obrazovne intervencije u svrhu usmjeravanja glazbenih preferencija prema kvalitetnoj, umjetnički vrijednoj glazbi rezultatima istraživanjima iskazuju Trammell (1978) i Moskovitz (1992). Oni eksperimentalno utvrđuju kako stručno, kompetentno vođeno slušanje uz višekratno ponavljanje djela s utvrđenim zadatkom slušanja ima pozitivne učinke na glazbene preferencije umjetničke, zapadne klasične glazbe, ali i kako ponavljanje umjetničkih glazbenih djela značajno utječe na bolje razumijevanje ove vrste glazbe i na uživanje u njoj. Kalkavage (2007) navodi kako najprije dolazi percepcija, a tek se onda javlja emocionalni odgovor. Autor smatra da se ispravan odnos prema estetskoj vrijednosti djela nalazi u uhu odgojenoga slušatelja te da su potrebni vrijeme i vježba da bi se vrijedna umjetnička djela uočila i shvatila. Small (1998) te Woody i Burns (2001) utvrđuju kako je generalno najznačajniji cilj glazbenog odgoja i obrazovanja upoznati učenike sa zapadnom klasičnom glazbom, jer će temeljem razumijevanja i stečenih preferencija prema ovoj glazbi moći razumjeti i glazbe drugih vrsta i žanrova, ali i kultura, jer se često klasična glazba u svojemu razvoju povezivala s glazbom drugih kultura i imala je utjecaj na druge glazbene vrste. Istraživanja ukazuju kako su preferencije prema glazbama pojedinih kultura povezane s poznavanjem pojedinih kulturoloških okvira (Knussen, 2003) i interkulturalnim stavovima učenika. Također pokazuju kako je veća preferencija prema glazbama svijeta iskazana u slučaju kada su djela prezentirana u aranžiranim verzijama, koje su bliske popularnoj glazbi, što je u suprotnosti s preporukama glazbenih pedagoga i etnomuzikologa koji naglašavaju važnost korištenja autentične snimke u nastavi (Campbell i Scott-Kassner, 2002). Shehan (1985) u svojoj studiji zaključuje kako glazbena poduka utječe na preferencije prema glazbama svijeta. U njezinoj studiji transfera preferencija učenici su u inicijalnom istraživanju iskazali najveće preferencije prema popularnoj glazbi, potom prema zapadnoeuropskoj klasičnoj glazbi, afričkoj, latino, indijskoj i japanskoj glazbi. Nakon pet tjedana, koliko je trajala glazbena poduka o glazbi i kulturi Afrike, Indije, Japana i Latinske Amerike, istraživanje je ukazalo na pomicanje i povećavanje glazbenih preferencija za glazbe svijeta. Testom je utvrđeno kako učenici i nadalje iskazuju najveće preferencije prema popularnoj glazbi, potom slijede afrička, hispanska i japanska glazba, a preferencije za klasičnu glazbu su se pomaknule na posljednje mjesto. 
Poznavanje glazbe ima značajnu ulogu u ostvarivanju glazbenih preferencija mladih. Stoga je od izrazitog značaja aktualizacija potrebe uvrštavanja glazbene poduke kroz različite odgojno-obrazovne školske programe.

\section{Istraživanje}

\section{Problem i cilj}

Uvidom u brojnu literaturu koja upućuju na raznolikost utjecaja na glazbene preferencije, istraživanje je provedeno s ciljem ispitivanja odnosa različitih varijabli i glazbenih preferencija srednjoškolaca u svrhu aktualizacije potrebe uvrštavanja glazbenih aktivnosti u školski kurikulum strukovnih srednjih škola. U skladu s utvrđenim problemom izdvojeni su sljedeći ciljevi istraživanja:

1. ispitati odnos sociodemografskih varijabli (dobi, spola, vrste škole i školskog uspjeha) i glazbenih preferencija učenika srednjih škola i njihovo poznavanje glazbenih stilova;

2. ispitati odnos sociodemografskih varijabli (dobi, spola, vrste škole i školskog uspjeha) i poznavanja, odnosno preferencija glazbenih stilova;

3. ispitati povezanost između poznavanja i preferencija glazbenih stilova;

4. utvrditi postoji li opravdanost za uvođenje nekog oblika glazbene poduke u strukovne škole

\section{Metoda $\mathrm{i}$ ispitanici}

Istraživanje je provedeno u Osijeku na uzorku od 408 učenika $(\mathrm{M}=183 ; \check{Z}=225)$ prvih i četvrtih razreda srednjih škola (Tablica 1). Sudjelovalo je 169 učenika strukovne škole (Ekonomska škola) i 239 učenika gimnazije (I. gimnazija). 
Tablica 1. Struktura uzorka sudionika $(\mathrm{N}=408)$

\begin{tabular}{|l|c|c|c|}
\hline Vrsta škole & Razred & Spol & N \\
\hline \multirow{4}{*}{ Gimnazija } & \multirow{2}{*}{ Prvi } & M & 61 \\
\cline { 3 - 4 } & & $\check{Z}$ & 69 \\
\cline { 3 - 4 } & \multirow{2}{*}{ Četvrti } & $\mathrm{M}$ & 60 \\
\cline { 3 - 4 } & & $\check{Z}$ & 49 \\
\hline \multirow{3}{*}{ Strukovna škola } & \multirow{2}{*}{ Prvi } & $\mathrm{M}$ & 30 \\
\cline { 3 - 4 } & \multirow{2}{*}{ Četvrti } & $\check{Z}$ & 58 \\
\cline { 3 - 4 } & & M & 32 \\
\cline { 3 - 4 } & & \multicolumn{2}{|c}{} \\
\hline
\end{tabular}

\section{Instrument i postupak istraživanja}

Kako bi se odredio odnos određenih sociodemografskih varijabli i glazbenih preferencija srednjoškolaca, u istraživanju je upotrijebljen prerađeni upitnik iz istraživanja Dobrota i Reić Ercegovac (2009). Upitnik se sastoji od dva dijela. Prvi dio upitnika sadrži pitanja koja se odnose na sociodemografska obilježja ispitanika (vrsta škole, razred, spol, školski uspjeh, stručna sprema roditelja, glazbeno obrazovanje roditelja). Drugi dio obuhvaća 15 glazbenih ulomaka umjetničke, popularne i glazbe svijeta. Kriteriji odabira primjera iz umjetničke glazbe temeljen je na Nastavnom planu i programu za osnovnu školu (2006), primjeri popularne glazbe odabrani su na temelju relevantnih svjetskih top-ljestvica, a primjeri glazbe svijeta po osobnom odabiru ispitivača.

Svaki je glazbeni ulomak prezentiran u svom karakterističnom dijelu, jednokratno, u trajanju od 30 do 45 sekundi (Tablica 2). Ispitanici su nakon odslušanog glazbenog ulomka procjenjivali stupanj sviđanja pojedinog ulomka na ljestvici Likertovog tipa zaokruživanjem brojeva od jedan (najniži) do pet (najviši). U sljedećem dijelu ispitanici su na ljestvici od jedan (nepoznato) i dva (poznato) procjenjivali poznatost svakog od odslušanih glazbenih ulomaka.

Ispitivanje je realizirano u potpunosti uz poštivanje etičkog kodeksa. Ispitanicima je objašnjena svrha provođenja istraživanja i zajamčena anonimnost. Nakon ispunjavanja prvog dijela upitnika s podatcima o sociodemografskim obilježjima, ispitanicima su dane točne upute o 
načinu provođenja glazbenog dijela ispitivanja, pri čemu su glazbeni primjeri određeni brojevima, bez imenovanja autora, izvođača ili glazbene vrste.

Tablica 2. Glazbeni primjeri u zvučnom upitniku

\begin{tabular}{|l|l|}
\hline \multicolumn{1}{|c|}{ Glazbeni stil } & \multicolumn{1}{c|}{ Glazbeni primjer } \\
\hline \multirow{5}{*}{ Umjetnička glazba } & $\begin{array}{l}\text { L. van Beethoven: Sonata za klavir u cis-molu, op. 27, } \\
\text { br. 2, Mjesečina (I stavak: Adagio sostenuto) }\end{array}$ \\
\cline { 2 - 3 } & $\begin{array}{l}\text { N. Paganini: Koncert za violinu, op. 7, br. 2, } \\
\text { La Campanella - III stavak: Rondo }\end{array}$ \\
\cline { 2 - 3 } & P. I. Čajkovski: Trepak, iz baleta Ščelkunčik \\
\cline { 2 - 3 } & $\begin{array}{l}\text { P. I. Čajkovski: Koncert za klavir u b-molu, I stavak: } \\
\text { Allegro non troppo e molto maestoso }\end{array}$ \\
\cline { 2 - 3 } & A. Borodin: Knez Igor, odlomak iz Polovjeckih plesova \\
\hline \multirow{5}{*}{ Popularna glazba } & Taylor Swift: Shake it off \\
\cline { 2 - 3 } & Nicki Minay: Anaconda \\
\cline { 2 - 3 } & Meghan Trainor: All about that bass \\
\cline { 2 - 3 } & Sam Smith: Stay with me \\
\cline { 2 - 3 } & Pharell Williams: Happy \\
\hline \multirow{5}{*}{ Julazbe svijeta } & Julian Avalos (Peru): Guajira Bonita \\
\cline { 2 - 3 } & Ernest Ranglin (Jamajka): Below the Bassline \\
\cline { 2 - 3 } & Los Tradicionales de Carols Puebla (Kuba): Dilema \\
\cline { 2 - 3 } & James »Bla« Pahinui (Havaji): Gabby Kai \\
\hline & $\begin{array}{l}\text { Ricardo Lemvo \& Makibna Loca (Congo): La Milonga } \\
\text { de Ricardo en Cha-cha-cha }\end{array}$ \\
\hline
\end{tabular}

\section{Rezultati i diskusija}

\section{Odnos sociodemografskih varijabli $i$ glazbenih preferencija}

Utvrđujući razliku u preferencijama s obzirom na vrstu škole utvrđeno je kako učenici koji pohađaju gimnazije značajno više preferiraju umjetničku glazbu i glazbe svijeta od učenika strukovne škole (Tablica 3). 
Tablica 3. Razlike u stupnju preferencija glazbenih stilova s obzirom na vrstu škole

\begin{tabular}{|l|c|c|c|c|c|c|c|}
\hline & \multicolumn{2}{|c|}{ Gimnazija } & \multicolumn{2}{|c|}{ Strukovna } & \multicolumn{2}{|c|}{} \\
\hline & $\boldsymbol{M}$ & $\boldsymbol{S} \boldsymbol{D}$ & $\boldsymbol{M}$ & $\boldsymbol{S} \boldsymbol{D}$ & $\boldsymbol{t}$-test & $\begin{array}{c}\text { Stupnjevi } \\
\text { slobode }\end{array}$ & $\begin{array}{c}\text { Stupanj } \\
\text { značajnosti }\end{array}$ \\
\hline $\begin{array}{l}\text { Preferencije } \\
\text { umjetničke glazbe }\end{array}$ & 17.15 & 3.244 & 14.48 & 4.682 & -6.82 & 406 & $.00^{* *}$ \\
\hline $\begin{array}{l}\text { Preferencije } \\
\text { popularne glazbe }\end{array}$ & 18.52 & 4.499 & 20.33 & 4.601 & 3.93 & 399 & $.00^{* *}$ \\
\hline $\begin{array}{l}\text { Preferencije } \\
\text { glazbe svijeta }\end{array}$ & 15.10 & 3.719 & 14.11 & 4.887 & -2.29 & 395 & $.02 *$ \\
\hline
\end{tabular}

* Značajnost na razini $p \leq 0.05$

** Značajnost na razini $p \leq 0.01$

Ostvarena statistički značajna razlika u preferencijama, usmjerenim prema umjetničkoj glazbi i glazbi svijeta, upućuje na utjecaje škole i glazbene nastave na ulazne podatke. Učenici općih gimnazija imaju tijekom cijelog četverogodišnjeg obrazovanja nastavu Glazbene umjetnosti u kojoj razvijaju glazbene kompetencije. Upoznavanjem glazbenih pojava učenici stvaraju osnovna slušna i teorijska znanja na osnovu kojih izgrađuju glazbene oblikovne strukture. Obrađujući glazbene oblike i vrste na umjetnički najvrjednijim skladbama raznih glazbenih stilova i žanrova, učenici koji pohađaju gimnaziju prepoznaju vrijednost umjetničke glazbe, razumiju jezik umjetničke glazbe i poruke koje ona nosi te uočavaju važan utjecaj umjetničke glazbe (Tablica 4). Iz ostvarenih rezultata uočavamo kako vrsta škole utječe na preferencije prema umjetničkoj glazbi i glazbi svijeta. Razmatrajući preferencije prema popularnoj glazbi zaključujemo kako i učenici gimnazije i učenici strukovne škole iskazuju najveće preferencije prema popularnoj glazbi (Slika 1). 
Tablica 4. Razlike u stupnju poznatosti glazbenih stilova s obzirom na vrstu škole

\begin{tabular}{|l|c|c|c|c|c|c|c|}
\hline & \multicolumn{2}{|l|}{ Gimnazija } & \multicolumn{2}{l|}{ Strukovna } & \multicolumn{2}{l|}{} \\
\hline & M & SD & M & SD & $t$-test & $\begin{array}{c}\text { Stupnjevi } \\
\text { slobode }\end{array}$ & $\begin{array}{c}\text { Stupanj } \\
\text { značajnosti }\end{array}$ \\
\hline $\begin{array}{l}\text { Poznatost } \\
\text { umjetničke } \\
\text { glazbe }\end{array}$ & 7.87 & 1.137 & 7.19 & 1.176 & -5.81 & 404 & $.00^{* *}$ \\
\hline $\begin{array}{l}\text { Poznatost } \\
\text { popularne glazbe }\end{array}$ & 9.53 & 1.044 & 9.37 & 1.102 & -1.49 & 398 & .14 \\
\hline $\begin{array}{l}\text { Poznatost } \\
\text { glazbe svijeta }\end{array}$ & 6.44 & 1.111 & 6.41 & 1,136 & -0.26 & 393 & .79 \\
\hline
\end{tabular}

** Značajnost na razini $p \leq 0.01$

Slika 1. Prikaz srednjih vrijednosti stupnja preferencija i stupnja poznatosti glazbenih stilova s obzirom na vrstu škole

\begin{tabular}{|c|c|c|c|c|c|}
\hline \multicolumn{3}{|c|}{$\begin{array}{l}\text { Stupanj preferencije glazbenih } \\
\text { stilova s obzirom na vrstu škole }\end{array}$} & \multicolumn{3}{|c|}{$\begin{array}{l}\text { Stupanj poznatosti glazbenih } \\
\text { stilova s obzirom na vrstu škole }\end{array}$} \\
\hline Glazbe svijeta & 15,1 & 14,11 & Glazbe svijeta & 6,44 & 6,41 \\
\hline Popularna glazba & 18,52 & 20,33 & Popularna glazba & 9,53 & 9,37 \\
\hline Umjetnička glazba & 17,15 & 14,48 & Umjetnička glazba & 7,87 & 7,19 \\
\hline \multicolumn{3}{|c|}{ Gimnazija $\quad$ Strukovna škola } & \multicolumn{3}{|c|}{ @ Gimnazija $=$ Strukovna škola } \\
\hline
\end{tabular}

Prilikom utvrđivanja razlike između preferencija s obzirom na spol zaključujemo kako djevojke značajno više preferiraju popularnu glazbu od mladića (Tablica 5), ali i značajno više prepoznaju glazbene odlomke koji pripadaju popularnoj glazbi nego što to prepoznaju mladići (Tablica 6). Dobiveni rezultati u skladu su s rezultatima brojnih istraživanja koja potvrđuju postojanje razlika između spolova u glazbenim preferencijama (Le Blanc, 1982; Hargreaves, Comber i Colley, 1995). Djevojke najčešće svoje glazbene preferencije temelje na emocionalnoj potrebi te glazbu popularnih žanrova odabiru sukladno svom osobnom mehanizmu regulacije raspoloženja (North, Hargreaves i O'Neill, 2000). Budući da odabrani primjeri, promatrani preko elemenata glaz- 
bene izražajnosti, pripadaju »mekšim « stilovima popularne glazbe za koji djevojke pokazuju veći stupanj prijemčivosti, rezultati u ovom dijelu ispitivanja bili su očekivani (Slika 2).

Tablica 5. Razlike u stupnju preferencija glazbenih stilova s obzirom na spol

\begin{tabular}{|l|c|c|c|c|c|c|c|}
\hline & \multicolumn{2}{|c|}{ Mladići } & \multicolumn{2}{c|}{ Djevojke } & & & \\
\hline & $M$ & $S D$ & $M$ & $S D$ & $t$-test & $\begin{array}{c}\text { Stupnjevi } \\
\text { slobode }\end{array}$ & $\begin{array}{c}\text { Stupanj } \\
\text { značajnosti }\end{array}$ \\
\hline $\begin{array}{l}\text { Preferencije } \\
\text { umjetničke } \\
\text { glazbe }\end{array}$ & 15.95 & 4.029 & 16.12 & 4.194 & -0.42 & 406 & .67 \\
\hline $\begin{array}{l}\text { Preferencije } \\
\text { popularne } \\
\text { glazbe }\end{array}$ & 17.88 & 4.789 & 20.41 & 4.162 & -5.67 & 399 & $.00^{* *}$ \\
\hline $\begin{array}{l}\text { Preferencije } \\
\text { glazbe svijeta }\end{array}$ & 14.94 & 4.127 & 14.47 & 4.390 & 1.06 & 395 & .29 \\
\hline
\end{tabular}

** Značajnost na razini $p \leq 0.01$

Tablica 6. Razlike u stupnju poznatosti glazbenih stilova s obzirom na spol

\begin{tabular}{|l|c|c|c|c|c|c|c|}
\hline & \multicolumn{2}{|c|}{ Mladići } & \multicolumn{2}{c|}{ Djevojke } & & & \\
\hline & $\boldsymbol{M}$ & $\boldsymbol{S D}$ & $\boldsymbol{M}$ & $\boldsymbol{S D}$ & $\boldsymbol{t}$-test & $\begin{array}{c}\text { Stupnjevi } \\
\text { slobode }\end{array}$ & $\begin{array}{c}\text { Stupanj } \\
\text { značajnosti }\end{array}$ \\
\hline $\begin{array}{l}\text { Poznatost } \\
\text { umjetničke } \\
\text { glazbe }\end{array}$ & 7.57 & 1.197 & 7.60 & 1.198 & -0.21 & 404 & .83 \\
\hline $\begin{array}{l}\text { Poznatost } \\
\text { popularne glazbe }\end{array}$ & 9.28 & 1.225 & 9.61 & 0.904 & -3.07 & 398 & $.00 * *$ \\
\hline $\begin{array}{l}\text { Poznatost glazbe } \\
\text { svijeta }\end{array}$ & 6.41 & 1.128 & 6.44 & 1.117 & -0.25 & 393 & .80 \\
\hline
\end{tabular}

** Značajnost na razini $p \leq 0.01$ 
Slika 2. Prikaz srednjih vrijednosti stupnja preferencija i stupnja poznatosti glazbenih stilova s obzirom na spol
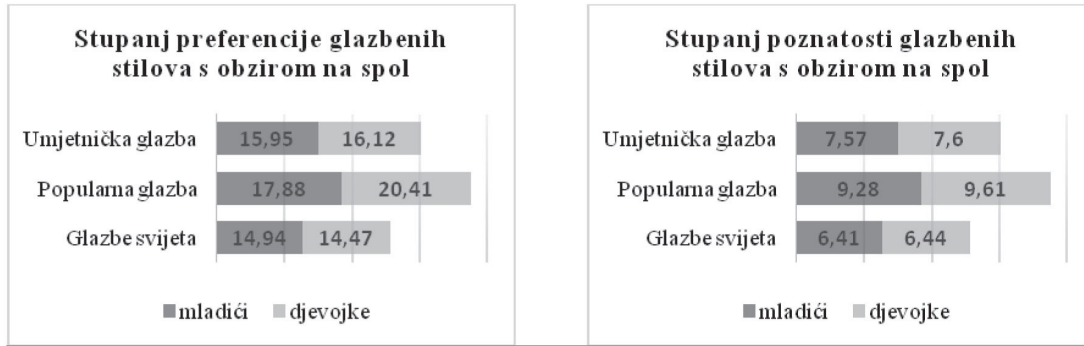

Iako je utvrđeno da učenici prvih i četvrtih razreda u najvećoj mjeri preferiraju popularnu glazbu, učenici prvih razreda ipak značajno više preferiraju popularnu glazbu od učenika četvrtih razreda (Tablica 7). Uočene smanjene preferencije za popularnu glazbu ukazuju na prisutnost elementa sazrijevanja učenika kao slušatelja koji su nakon tri godine izmijenili razinu glazbenog obrazovanja.

$\mathrm{Na}$ temelju dobivenih rezultata utvrđujemo kako učenici četvrtih razreda značajno više preferiraju glazbe svijeta, što ukazuje na obrazovne promjene ostvarene pod utjecajem glazbene nastave, ali i spoznajne promjene ostvarene kroz ostale nastavne predmete s kojima se ostvaruje nastavna korelacija tijekom srednjoškolskog obrazovanja.

Tablica 7. Razlike u stupnju preferencija glazbenih stilova s obzirom na dob

\begin{tabular}{|l|c|c|c|c|c|c|c|}
\hline & \multicolumn{2}{|c|}{ 1. razred } & \multicolumn{2}{c|}{ 4. razred } & & & \\
\hline & $\boldsymbol{M}$ & $\boldsymbol{S D}$ & $\boldsymbol{M}$ & $\boldsymbol{S D}$ & $\boldsymbol{t}$-test & $\begin{array}{c}\text { Stupnjevi } \\
\text { slobode }\end{array}$ & $\begin{array}{c}\text { Stupanj } \\
\text { značajnosti }\end{array}$ \\
\hline $\begin{array}{l}\text { Preferencije } \\
\text { umjetničke } \\
\text { glazbe }\end{array}$ & 15.79 & 4.249 & 16.33 & 3.950 & -1.31 & 406 & .19 \\
\hline $\begin{array}{l}\text { Preferencije } \\
\text { popularne } \\
\text { glazbe }\end{array}$ & 19.81 & 4.188 & 18.69 & 5.013 & 2.42 & 399 & $.02 *$ \\
\hline $\begin{array}{l}\text { Preferencije } \\
\text { glazbe svijeta }\end{array}$ & 14.17 & 4.427 & 15.25 & 4.036 & -2.55 & 395 & $.01 * *$ \\
\hline
\end{tabular}

* Značajnost na razini $p \leq 0.05$

$* *$ Značajnost na razini $p \leq 0.01$ 
Učenici četvrtih razreda značajno više navode da poznaju umjetničku glazbu od učenika prvih razreda, što direktno upućuje na zaključak o razvojnoj tendenciji formiranja glazbenih preferencija.

Tablica 8. Razlike u stupnju preferencija glazbenih stilova učenika strukovne škole s obzirom na dob

\begin{tabular}{|l|c|c|c|c|c|c|c|}
\hline & \multicolumn{2}{|c|}{ 1. razred } & \multicolumn{2}{|c|}{ 4. razred } & & & \\
\hline & $\boldsymbol{M}$ & $\boldsymbol{S D}$ & $\boldsymbol{M}$ & $\boldsymbol{S D}$ & $\boldsymbol{t}$-test & $\begin{array}{c}\text { Stupnjevi } \\
\text { slobode }\end{array}$ & $\begin{array}{c}\text { Stupanj } \\
\text { značajnosti }\end{array}$ \\
\hline $\begin{array}{l}\text { Preferencije } \\
\text { umjetničke } \\
\text { glazbe }\end{array}$ & 14.07 & 4.935 & 14.93 & 4.378 & -1.19 & 167 & .24 \\
\hline $\begin{array}{l}\text { Preferencije } \\
\text { popularne } \\
\text { glazbe }\end{array}$ & 20.39 & 4.584 & 20.26 & 4.646 & 0.18 & 167 & .86 \\
\hline $\begin{array}{l}\text { Preferencije } \\
\text { glazbe svijeta }\end{array}$ & 13.57 & 5.013 & 14.69 & 4.710 & -1.49 & 166 & .14 \\
\hline
\end{tabular}

Temeljem ostvarenih rezultata koji iskazuju da ne postoji statistički značajna razlika u stupnju preferencija glazbenih stilova između učenika prvih i četvrtih razreda strukovne škole (Tablica 8), zaključujemo da dominantne preferencije prema popularnoj glazbi ostaju tijekom cijelog srednjoškolskog obrazovanja kod ispitanika koji pohađaju strukovnu školu. Razvojna tendencija u pomaku preferencija prema drugim glazbenim vrstama nije utvrđena. Dobiveni rezultati u skladu su s rezultatima istraživanja Škojo (2016) koji potvrđuju utjecaj vrste srednjoškolskog obrazovanja na glazbene preferencije. Iz ustanovljenog nepostojanja statistički značajne razlike u stupnju poznatosti glazbenih stilova učenika strukovne škole, utvrđujemo kako niti u ovome dijelu nema razvojnih promjena. 
Tablica 9. Razlike u stupnju preferencija glazbenih stilova učenika gimnazije s obzirom na dob

\begin{tabular}{|l|c|c|c|c|c|c|c|}
\hline & \multicolumn{2}{|c|}{ 1. razred } & \multicolumn{2}{c|}{ 4. razred } & & & \\
\hline & $\boldsymbol{M}$ & $\boldsymbol{S} \boldsymbol{D}$ & $\boldsymbol{M}$ & $\boldsymbol{S} \boldsymbol{D}$ & $\boldsymbol{t}$ - test & $\begin{array}{c}\text { Stupnjevi } \\
\text { slobode }\end{array}$ & $\begin{array}{c}\text { Stupanj } \\
\text { značajnosti }\end{array}$ \\
\hline $\begin{array}{l}\text { Preferencije } \\
\text { umjetničke } \\
\text { glazbe }\end{array}$ & 16.97 & 3.244 & 17.38 & 3.245 & -0.97 & 237 & .34 \\
\hline $\begin{array}{l}\text { Preferencije } \\
\text { popularne } \\
\text { glazbe }\end{array}$ & 19.39 & 3.848 & 17.52 & 4.977 & 3.23 & 230 & $.00^{* *}$ \\
\hline $\begin{array}{l}\text { Preferencije } \\
\text { glazbe svijeta }\end{array}$ & 14.59 & 3.919 & 15.68 & 3.409 & -2.21 & 227 & $.03^{*}$ \\
\hline
\end{tabular}

* Značajnost na razini $p \leq 0.05$

** Značajnost na razini $p \leq 0.01$

Kroz rezultate je razvidna statistički značajna razlika u stupnju preferencija glazbenih stilova između učenika prvih i četvrtih razreda gimnazije, pri čemu učenici prvih razreda više od učenika četvrtih razreda preferiraju popularnu glazbu, dok učenici četvrtih razreda više preferiraju glazbe svijeta od učenika prvih razreda. Utvrđujemo kako su učenici kroz nastavu Glazbene umjetnosti stekli znanja o glazbama različitih naroda i temeljem toga razvili slušnu toleranciju prema novim zvučnim sklopovima što je rezultiralo razvojem preferencija. Iz rezultata proizlazi kako je utjecaj glazbene poduke u ovom razvojnom razdoblju učenika presudan za formiranje pozitivnog odnosa prema različitim glazbenim pravcima. 
Tablica 10. Razlike u stupnju poznatosti glazbenih stilova gimnazije s obzirom na dob

\begin{tabular}{|l|c|c|c|c|c|c|c|}
\hline & \multicolumn{2}{|c|}{ 1. razred } & \multicolumn{2}{|c|}{ 4. razred } & & & \\
\hline & $\boldsymbol{M}$ & $\boldsymbol{S D}$ & $\boldsymbol{M}$ & $\boldsymbol{S D}$ & $\boldsymbol{t}$-test & $\begin{array}{c}\text { Stupnjevi } \\
\text { slobode }\end{array}$ & $\begin{array}{c}\text { Stupanj } \\
\text { značajnosti }\end{array}$ \\
\hline $\begin{array}{l}\text { Poznatost } \\
\text { umjetničke } \\
\text { glazbe }\end{array}$ & 7.53 & 1.155 & 8.27 & 0.968 & -5.27 & 237 & $.00 * *$ \\
\hline $\begin{array}{l}\text { Poznatost } \\
\text { popularne } \\
\text { glazbe }\end{array}$ & 9.49 & 1.246 & 9.57 & 0.751 & -0.59 & 230 & .55 \\
\hline $\begin{array}{l}\text { Poznatost } \\
\text { glazbe svijeta }\end{array}$ & 6.44 & 1.158 & 6.44 & 1.061 & -0.2 & 226 & .99 \\
\hline
\end{tabular}

** Značajnost na razini $p \leq 0.01$

Dok kod učenika koji pohađaju strukovnu školu nisu utvrđene značajne razlike u stupnju poznatosti s obzirom na dob (Slika 3), kod učenika koji pohađaju gimnaziju utvrđena je statistički značajna razlika u stupnju poznatosti glazbenih stilova (Tablica 10), pri čemu učenici četvrtih razreda gimnazije značajno više navode kako poznaju umjetničku glazbu od učenika prvih razreda (Slika 3) što direktno upućuje na zaključak o utjecaju glazbene nastave na formiranje glazbenih znanja koja omogućuju dobro poznavanje umjetničke glazbe i šire njegovu glazbenu spoznaju.

Slika 3. Prikaz srednjih vrijednosti stupnja poznatosti glazbenih primjera s obzirom na dob
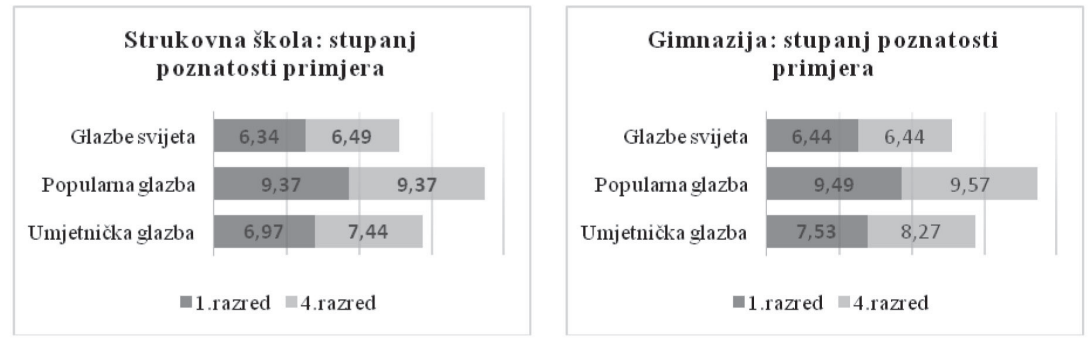

Korelacije između preferencija i poznavanja glazbenih stilova (Tablica 11) ukazuju na značajnu povezanost između preferencija i pozna- 
vanja popularne glazbe, preferencija i poznavanja glazbi svijeta te preferencija i poznavanja umjetničke glazbe. Koeficijenti korelacije koji su se pokazali statistički značajnima su niski ili umjereni. Umjerene povezanosti pokazale su se između rezultata preferencija umjetničke i glazbe svijeta $(\mathrm{r}=0.51)$ što pokazuje kako sudionici istraživanja koji preferiraju umjetničku glazbu također preferiraju i glazbe svijeta.

Povezanost između preferencija umjetničke glazbe i glazbe svijeta ukazuje na utjecaj glazbene edukacije na preferencije, jer učenici koji imaju glazbena znanja i sposobnosti te shvaćaju vrijednost ove glazbe imaju i razvijene glazbene preferencije usmjerene prema tim vrstama glazbe. Do istog zaključka dolazi se analiziranjem rezultata koji iskazuju da sudionici koji preferiraju umjetničku glazbu također poznaju umjetničku glazbu ( $\mathrm{r}=0.46)$ i glazbe svijeta $(\mathrm{r}=0.22)$, a sudionici koji preferiraju glazbe svijeta poznaju umjetničku ( $\mathrm{r}=0.21)$ i glazbe svijeta (r=0.34). Možemo zaključiti da ispitanici koji poznaju umjetničku glazbu poznaju i popularnu glazbu $(\mathrm{r}=0.20)$ i glazbe svijeta $(\mathrm{r}=0.31)$, odnosno kompetentni su poznavatelji glazbenih vrsta i žanrova.

Tablica 11. Povezanost između preferencija i poznatosti glazbenih stilova ( $N=408)$

\begin{tabular}{|c|c|c|c|c|c|c|}
\hline & 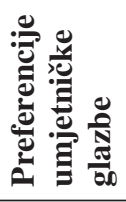 & 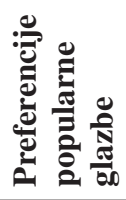 & 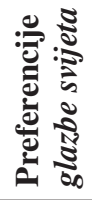 & 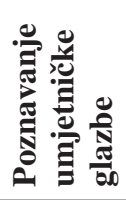 & 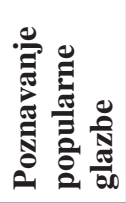 & 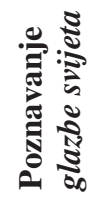 \\
\hline $\begin{array}{l}\text { Preferencije } \\
\text { umjetničke } \\
\text { glazbe }\end{array}$ & 1 & $.16 * *$ & $.51 * *$ & $.46^{* * *}$ & .07 & $.22 * *$ \\
\hline $\begin{array}{l}\text { Preferencije po- } \\
\text { pularne glazbe }\end{array}$ & & 1 & $.27 * *$ & -.05 & $.21 * *$ & .02 \\
\hline $\begin{array}{l}\text { Preferencije } \\
\text { glazbe svijeta }\end{array}$ & & & 1 & $.21 * *$ & .00 & $.34 * *$ \\
\hline $\begin{array}{l}\text { Poznavanje } \\
\text { umjetničke } \\
\text { glazbe }\end{array}$ & & & & 1 & $.20 * *$ & $.31 * *$ \\
\hline $\begin{array}{l}\text { Poznavanje po- } \\
\text { pularne glazbe }\end{array}$ & & & & & 1 & .03 \\
\hline $\begin{array}{l}\text { Poznavanje } \\
\text { glazbe svijeta }\end{array}$ & & & & & & 1 \\
\hline
\end{tabular}


Tablica 12. Razlike u stupnju preferencija glazbenih stilova s obzirom na školski uspjeh i stručnu spremu roditelja

\begin{tabular}{|l|l|c|c|c|}
\hline Zavisne varijable & & F & $\begin{array}{c}\text { Stupnjevi } \\
\text { slobode }\end{array}$ & $\begin{array}{c}\text { Stupanj } \\
\text { značajnosti }\end{array}$ \\
\hline \multirow{3}{*}{$\begin{array}{l}\text { Preferencije } \\
\text { umjetničke glazbe }\end{array}$} & Školski uspjeh & 3.60 & $4 / 401$ & $.01^{* *}$ \\
\cline { 2 - 5 } & Stručna sprema oca & 1.08 & $4 / 400$ & .37 \\
\cline { 2 - 5 } & Stručna sprema majke & 0.69 & $4 / 399$ & .59 \\
\hline \multirow{3}{*}{$\begin{array}{l}\text { Preferencije } \\
\text { popularne glazbe }\end{array}$} & Školski uspjeh & 4.00 & $3 / 395$ & $.01^{* *}$ \\
\cline { 2 - 5 } & Stručna sprema oca & 0.87 & $4 / 393$ & .48 \\
\cline { 2 - 5 } & Stručna sprema majke & 3.47 & $4 / 392$ & $.01 * *$ \\
\hline \multirow{3}{*}{$\begin{array}{l}\text { Preferencije glazbi } \\
\text { svijeta }\end{array}$} & Školski uspjeh & 0.23 & $3 / 391$ & .88 \\
\cline { 2 - 5 } & Stručna sprema oca & 0.13 & $4 / 389$ & .97 \\
\cline { 2 - 5 } & Stručna sprema majke & 1.14 & $4 / 388$ & .34 \\
\hline
\end{tabular}

Iz dobivenih rezultata uočavamo da postoji statistički značajna razlika u preferencijama umjetničke glazbe s obzirom na školski uspjeh, pri čemu učenici koji su prošli s izvrsnim uspjehom na kraju prethodne školske godine $(M=16.75)$ značajno više preferiraju umjetničku glazbu od učenika koji su prošli s dobrim uspjehom $(\mathrm{M}=14.54)$. Utvrđujemo kako su učenici koji ostvaruju ukupan odličan uspjeh u školi motiviraniji i uspješniji i u glazbenoj nastavi. Stoga zaključujemo kako je obrazovanje i stručna glazbena intervencija od najveće važnosti za oblikovanje preferencija za umjetničku glazbu i usmjeravanje te proširivanje preferencija prema umjetničkoj glazbi (LeBlanc, 1981). Rezultati ukazuju da ne postoji značajna razlika u preferencijama umjetničke glazbe s obzirom na stručnu spremu roditelja, što ukazuje na dominaciju škole i neznatan utjecaj obitelji kao glazbeno odgojno-obrazovnog čimbenika za usmjeravanje preferencija prema umjetničkoj glazbi.

Utvrđena statistički značajna razlika u preferencijama popularne glazbe - učenici koji u prošli s izvrsnim uspjehom $(M=19.95)$ značajno više preferiraju popularnu glazbu od učenika koji su prošli s vrlo dobrim uspjehom $(\mathrm{M}=18.95)$ - ukazuje na prisutnu izraženiju motiviranost učenika s izvrsnim uspjehom za slušanje aktualne glazbe. 
Tablica 13. Razlike u stupnju poznatosti glazbenih stilova s obzirom na školski uspjeh i stručnu spremu roditelja

\begin{tabular}{|l|l|c|c|c|}
\hline Poznatost & Nezavisne varijable & F & $\begin{array}{c}\text { Stupnjevi } \\
\text { slobode }\end{array}$ & $\begin{array}{c}\text { Stupanj } \\
\text { značajnosti }\end{array}$ \\
\hline \multirow{3}{*}{$\begin{array}{l}\text { Poznatost } \\
\text { umjetničke glazbe }\end{array}$} & Školski uspjeh & 1.81 & $3 / 400$ & .15 \\
\cline { 2 - 5 } & Stručna sprema oca & 1.08 & $4 / 398$ & .37 \\
\cline { 2 - 5 } & Stručna sprema majke & 3.17 & $4 / 397$ & .14 \\
\hline \multirow{3}{*}{$\begin{array}{l}\text { Poznatost } \\
\text { popularne glazbe }\end{array}$} & Školski uspjeh & 0.47 & $3 / 394$ & .70 \\
\cline { 2 - 5 } & Stručna sprema oca & 1.25 & $4 / 392$ & .29 \\
\cline { 2 - 5 } & Stručna sprema majke & 1.22 & $4 / 391$ & .30 \\
\hline \multirow{2}{*}{$\begin{array}{l}\text { Poznatost glazbi } \\
\text { svijeta }\end{array}$} & Školski uspjeh & 1.27 & $3 / 389$ & .28 \\
\cline { 2 - 5 } & Stručna sprema oca & 0.59 & $4 / 388$ & .67 \\
\cline { 2 - 5 } & Stručna sprema majke & 1.28 & $4 / 386$ & .28 \\
\hline
\end{tabular}

Iz ostvarenih rezultata možemo utvrditi da ne postoji statistički značajna razlika u poznavanju glazbenih stilova s obzirom na školski uspjeh i stručnu spremu roditelja.

\section{Zaključak}

Glazbene aktivnosti koje se provode u glazbenoj nastavi ili izvannastavnim glazbenim aktivnostima važan su element u odgoju i obrazovanju učenika. Putem tih aktivnosti mladi stječu brojne glazbene kompetencije, oplemenjuju život umjetničkim sadržajima i formiraju vrijedne estetičke stavove. Aktivnim analitičkim slušanjem permanentno se razvojno utječe na kognitivne sposobnosti mladih i na percepciju složenosti glazbe. Upoznavanjem različite glazbe mladi povećavaju svoju glazbenu prijemčivost i proširuju opseg glazbenih preferencija.

Uz pomoć glazbene poduke, umjetnička glazba, klasična i avangardna, učenicima postaje poznata, a njezina estetska vrijednost pozitivno utječe na ukus učenika i doživljavanje lijepog u umjetničkom stvaralaštvu. Nakon glazbene, ali i interdisciplinarno usmjerene poduke, glazbe svijeta, iako geografski daleke, postaju preferencijama bliske i zanimljive mladima. Popularna glazba i kvalitetan repertoarni odabir iz ove vrste glazbe pomoću adekvatne glazbene poduke može navesti 
da slušanje s pasivno-emocionalne dimenzije preraste u novu kognitivno-afektivnu dimenziju i na taj način uspostavi kod mladih slušatelja nove kriterije odabira glazbenih djela i novo usmjeravanje glazbenih preferencija.

Iz dobivenih rezultata retestnom formom je potvrđeno postojanje odnosa sociodemografskih varijabli dobi, spola, vrste škole i školskog uspjeha i naobrazbe roditelja na glazbene preferencije učenika srednjih škola i na poznavanje glazbenih stilova te je potvrđena povezanost između poznavanja i preferencija glazbenih stilova (Dobrota i Reić Ercegovac, 2009).

Ukazujemo na značajan utjecaj obrazovnih sadržaja s područja glazbe koji se ostvaruju u gimnazijama na razvoj glazbenih preferencija mladih. Iako su preferencije i kod učenika strukovne škole i kod učenika gimnazija dominantno usmjerene prema popularnoj glazbi, učenici gimnazija, koji su pod utjecajem glazbene poduke tijekom četverogodišnjeg srednjoškolskog školovanja sustavno razvijali slušna znanja i sposobnosti te širili svoje glazbene preferencije prema novim glazbenim stilovima, iskazuju značajno veće preferencije prema umjetničkoj glazbi i toleranciju prema novim zvučnim sklopovima što je rezultiralo razvojem glazbenih preferencija prema glazbama svijeta. Zaključujemo da je potrebno implementirati glazbene odgojno-obrazovne sadržaje u obrazovne institucije u kojima nisu zastupljeni, ali i intenzivirati glazbenu poduku kroz različita programska proširenja te izvannastavne aktivnosti kako bi mladi u svojoj formativnoj fazi gradili pozitivan odnos prema glazbenoj umjetnosti, otvorenost i toleranciju prema različitim kulturama i subkulturnim fenomenima te, u konačnici, širenjem svojih glazbenih preferencija obogatili osobni i društveni kulturni život.

\section{Literatura}

Andreis, Josip (1967), Vječni Orfej, Zagreb: Školska knjiga.

Arnett, Jeffrey Jensen (1995), »Adolescents uses of media for self-socialisation «, Journal of Youth and Adolescence, 24, str. 519-533. doi: https://doi.org/10.1007/BF01537054

Baptiste, Renee L.; Ma Zenia Augustin (2009), »Folk-song preferences of music student in middle high «, Kodaly Envoy, str. 35.

Breintenfeld, Darko; Majsec Vrbanić, Valerija (2011), Muzikoterapija: pomognimo si glazbom, Zagreb: Music play. 
Burnsed, Vernon (2001), »Differences in preference for subtle dynamic nuance between conductors, middle school students, and elementary school students «, Journal of Research in Music Education, 49, str. 49-56. doi: https://doi.org/10.2307/3345809

Campbell, Patricia Shehan; Scott-Kassner, Carol (2002), Music in Childhood, Belmont, CA: Wadsworth Group.

Cripe, Frances F. (1986), »Rock music as therapy for children with attention deficit disorder: An exploratory study«, Journal of Music Therapy, 13(1), str. 30-37. doi: https://doi.org/10.1093/jmt/23.1.30

Crowder, Robert G. (1984), »Perception of the major/minor distinction: Historical and theoretical foundation «, Psychomusicology, 4, str. 3-12.

doi: https://doi.org/10.1037/h0094207

Dobrota, Snježana; Reić Ercegovac, Ina (2009), »Glazbene preferencije mladih s obzirom na neke sociodemografske varijable«, Odgojne znanosti, 11(2), str. 381-398.

Eysenck, Hans (1990), »Biological dimensions of personality«, u: Pervin, A. Lawrence (ur.), Handbook of Personality: Theory and Research, New York: Guilford, str. 244-276.

Farnsworth, Paul R. (1969), The Social Psychology of Music, Iowa: The Iowa State University Press.

Frith, Simon (1996), Performing Rites. On the Value of Popular Music, Oxford: Oxford University Press.

Gaggiolo, Amedeo (2003), Educazione musicale e nuove technologie, Torino: EDT.

Gantz, Walter; Gartenberg, Howard M.; Pearson, Martin L.; Schiller, Seth (1978), $\gg$ Gratifications and expectations associated with popular music among adolescents«, Popular Music and Society, 6, str. 81-89.

doi: https://doi.org/10.1080/03007767808591113

Gregory, Dianne (1994), »Analysis of listening preferences of high school and college musicians «, Journal of Research in Music Education, 42(4), str. 331342. doi: https://doi.org/10.2307/3345740

Hargreaves, David J.; Colman, Andrew M. (1981), »The dimensions of aesthetic reactions to music «, Psychology of Music, 9, str. 15-20. doi: https://doi.org/10.1177/03057356810090010301

Hargreaves, David J.; Comber, Chris; Colley, Ann (1995), »Effects of age, gender, and training on musical preferences of British secondary school students «, Journal of Research in Music Education, 43, str. 242-250.

doi: https://doi.org/10.2307/3345639 
Kalkavage, Peter (2007), »Zapostavljena muza - zašto je glazba bitna slobodna umjetnost?«, Tonovi, 50, str. 80-86.

Knussen, Sue (2003), „Educational programmes «, u: Lawson, Colin (ur.), The Cambridge Companion to the Orchestra, New York, NY: Cambridge University Press, str. 239-250. doi: https://doi.org/10.1017/CCOL9780521806589.015

Krugman Herbert E. (1943), »Affective responses to music as a function of familiarity «, The Journal of Abnormal and Social Psychology, 38, str. 388-392. doi: https://psycnet.apa.org/doi/10.1037/h0061528

Kuntsche, Emanuel; Le Mével, Lydie; Berson, Irina (2016), »Development of the four-dimensional Motives for Listening to Music Questionnaire (MLMQ) and associations with health and social issues among adolescents «, Psychology of Music, 44, str. 219-233. doi: https://doi.org/10.1177/0305735614562635

Lamont, Alexandra; Hargreaves, David J.; Marshall, Nigel A.; Tarrant, Mark (2003), »Young people's music in and out of school«, British Journal of Music Education, 20(3), str. 229-241. doi: https://doi.org/10.1017/S0265051703005412

Larson, Reed (1985), »Secrets in the bedroom: Adolescents' private use of media«, Journal of Youth and Adolescence, 24, str. 535-550.

doi: https://doi.org/10.1007/BF01537055

Lippman, Julia R.; Greenwood, Dara N. (2012), »A song to remember: Emerging adults recall memorable music «, Journal of Adolescent Research, 1(27), str. 751-774. doi: https://doi.org/10.1177/0743558412447853

LeBlanc, Albert (1981), »Effects of style, tempo and performing medium on children's music preference «, Journal of Research in Music Education, 29(2), str. 143-156. doi: https://doi.org/10.2307/3345023

Le Blanc, Albert (1982), »An interactive theory of music preference«, Journal of Music Therapy, 19, str. 28-45. doi: https://doi.org/10.1093/jmt/19.1.28

LeBlanc, Albert; Cote, Richard (1983), »Effects of tempo and performing medium on children's music preference «, Journal of Research in Music Education, 31, str. 57-66. doi: https://doi.org/10.2307/3345110

LeBlanc, Albert; Sherrill, Carolyn (1986), »Effect of vocal vibrato and performer's sex on children's music preference«, Journal of Research in Music Education, 34, str. 222-237. doi: https://doi.org/10.2307/3345258

LeBlanc, Albert; Sims, Wendy L.; Malin, Sue A.; Sherrill, Carolyn (1992), »Relationship between humor perceived in music and preferences of different-age listeners«, Journal of Research in Music Education, 40, str. 269-282. doi: https://doi.org/10.2307/3345835

Lull, James (1985), »On the communicative properties of music «, Communication Research, 12, str. 363-372. doi: https://doi.org/10.1177/009365085012003008

Mirković-Radoš, Ksenija (1996), Psihologija muzike, Beograd: Zavod za udžbenike i nastavna sredstva. 
Moskovitz, Elisa M. (1992), »The effect of repetition on tempo preference of elementary children«, Journal of Research in Music Education, 40, str. 193-203. doi: https://doi.org/10.2307/3345681

Moore, Randall; Johnson, David (2001), »Effects of musical experience on perception of and preference for humor in Western art music«, Bulletin of the Council for Research in Music Education, 149, str. 31-37.

Nastavni plan i program za osnovnu školu (2006). Zagreb: Ministarstvo znanosti, obrazovanja i športa Republike Hrvatske.

North, Adrian C.; Hargreaves, David J.; O’Neill, Susan A. (2000), »The importance of music to adolescents «, British Journal of Education Psychology, 70, str. 255-272. doi: https://doi.org/10.1348/000709900158083

Njirić, Nikša (1974), Upoznavanje glazbenih djela i osnovnih glazbenih oblika u osnovnoj školi. Upute i komentari uz gramofonske ploče. Priručnik za nastavnike, Zagreb: Školska knjiga - Jugoton.

Rentfrow, Peter J.; Gosling, Samuel D. (2003), »The do re mi's of everyday life: examining the structure and personality correlates of music preferences «, Journal of Personality and Social Psychology, 84, str. 1236-1256. doi: https://doi.org/10.1037/0022-3514.84.6.1236

Rojko, Pavel (1996), Metodika nastave glazbe. Teorijsko - tematski aspekti, Osijek: Sveučilište Josipa Jurja Strossmayera.

Rojko, Pavel (2005), Metodika glazbene nastave-praksa II. Dio: Slušanje glazbe, Zagreb: Jakša Zlatar.

Rojko, Pavel (2007), »Znanje o glazbi nasuprot glazbenom znanju«, Tonovi, 49, str. 71-91.

Saarikallio, Suvi H. (2008), »Music in mood regulation: Initial scale development «, Musicae Scientiae, 12, str. 291-309. doi: https://doi.org/10.1177/102986490801200206

Sagalnik, Matthew J.; Dodds, Peter S.; Watts, Duncan J. (2006), »Experimental study of inequality and unpredictability in an artificial cultural market «, Science, 311, str. 854-856. doi: https://doi.org/10.1126/science.1121066

Schäfer, Thomas; Smukalla, Mario; Oelker, Sarah-Ann (2014), »How music changes our lives: A qualitative study of the long-term effects of intense musical experiences «, Psychology of Music, 42(4) str. 525-544. doi: https://doi.org/10.1177/0305735613482024

Scheel, Karen R.; Westefeld, John S. (1999), »Heavy metal music and adolescent suicidality: An empirical investigation «, Adolescence, 34(134), str. 253-273.

Shehan, Patricia K. (1981), »Student preferences for ethnic music styles«, Music Education Journal, 9, str. 21-28. 
Shehan, Patricia K. (1985), »Transfer of preference from taught to untaught pieces of non-Western music genres «, Journal of Research in Music Education, 33, str. 149-158. doi: https://doi.org/10.2307/3344802

Škojo, Tihana; Radočaj-Jerković, Antoaneta; Milinović, Majda (2016), »Utjecaj zborskoga pjevanja na razvoj glazbenih preferencija djece predškolske dobi«, u: Jukić, Renata; Bogatić, Katarina; Gazibara, Senka; Pejaković, Sara; Simel, Sanja; Nagy, Varga A. (ur.), Globalne i lokalne perspektive pedagogije, Osijek: Filozofski fakultet u Osijeku, str. 59-72.

Škojo, Tihana (2016), »Glazbene preferencije učenika kao polazište za realizaciju izvannastavnih aktivnosti u strukovnim školama«, Život $i$ škola: časopis za teoriju i praksu odgoja i obrazovanja, 62(2), str. 169-186.

Small, Christopher (1998), Musicking: The Meanings of Performing and Listening, Hanover: Wesleyan University Press.

Smith, David J. (1987), »Conflicting aesthetic ideal sin a musical culture«, Music Perception, 4, str. 373-391. doi: https://doi.org/10.2307/40285380

Šuran, Fulvio (2013), »Glazba i mediji s posebnim osvrtom na film«, In medias Res, 2, str. 124-146.

Thompson, William F.; Schellenberg, Glenn E.; Husain, Gabriela (2001), »Arousal, mood and the Mozart Effect «, Psychological Science, 12(3), str. 248251. doi: https://doi.org/10.1111/1467-9280.00345

Trammell, P. T. (1978), An Investigation of the Effectiveness of Repetition on Guided Listening in Developing Enjoyable Music Listening Experience for Second Grade Students, doctoral dissertation.

Uhlig, Sylka; Jansen, Erik; Schreder, Erik (2015), »Study protocol Rap Music Therapy for emotion regulation in a school setting «, Psyhology of Music, 44(5), str. 1068-1081. doi: https://doi.org/10.1177/0305735615608696

Van der Zwaag, Marjolein D.; Eesterink, Joyce H. D. M.; van der Broek, Egon L. (2011), »Emotional and psychophysiological responses to tempo, mode and percussiveness «, Musicae Scietiae, 15(2), str. 250-269. doi: https://doi.org/10.1177/1029864911403364

Woody, Robert H.; Burns, Kimberly J. (2001), »Predicting music appreciation with past emotional responses to music «, Journal of Research in Music Education, 49, str. 57-70. doi: https://doi.org/10.2307/3345810 


\title{
THE RELATIONSHIP BETWEEN THE MUSICAL PREFERENCES OF SECONDARY SCHOOL STUDENTS, MUSIC EDUCATION, AND SOCIO-DEMOGRAPHIC VARIABLES
}

\author{
Tihana Škojo
}

The numerous factors affecting secondary school students' musical preferences show how difficult the role of music educators is. Their task is to use competent, creative music teaching to lead students away from an emotional, connotative approach towards a syntactic strategy of listening, to develop analytical musicological processes, and to gradually develop their musical tastes with a highquality aesthetic value system. Research into the relationship between socio-demographic variables and musical preferences among students in year 1 and year 4 of gymnasiums and vocational schools has affirmed differences in knowledge of and preferences in attested musical styles according to sex, type of school, age, and academic performance. The results of this research indicate the need to include music instruction in vocational schools, educational institutions that lack music programmes, as well as the need to increase the breadth of existing music programmes so that young people in their formative years, in addition to building a positive relationship towards artistic music, develop openness and tolerance towards various cultures and subcultural phenomena.

Key words: adolescent musical preferences, music instruction, artistic music, popular music, world music 